\title{
Students are our future
}

\author{
It is not an overstatement to say that the future of optics and photonics lies in the hands of students. \\ Every little investment, be it intellectual or financial, can potentially yield immeasurable returns.
}

It is exciting to see how advances in optics and photonics are enhancing the quality of our daily lives and it is gratifying to witness the proclamation of 2015 as the International Year of Light and Lightbased Technologies (IYL 2015) by the United Nations.

While relishing the fact that the future belongs to optics and photonics, we shouldn't forget that the future of the field lies in the hands of students. Students are tomorrow's leaders, scientists, inventors, entrepreneurs and engineers. This makes every little investment into students, be it intellectual or financial, worthwhile. Fortunately, the optics and photonics community actively provides diverse opportunities and support for students.

The two main optical societies - the International Society of Optics and Photonics (SPIE) and the Optical Society of America (OSA) - provide a great range of services to their student members.

Of these services, the most popular are their student chapter programmes. Both societies have extensive global networks of student chapters. These chapters, managed by students for students, create valuable opportunities and help foster lasting relationships with peers and mentors. The exclusive benefits student members receive include travel grants for conferences, educational scholarships, visiting lecturer grants, excellence awards, leadership and professional development workshops, networking with experts, mentoring and outreach.

"Through SPIE student chapters, students get the opportunity to reach out beyond the walls of their home institution to tap into the expertise of technical experts, optics industry leaders and their local community," said Dirk Fabian, the SPIE Student Services Lead. The chapters also provide students with the resources for developing their professional skills, particularly leadership and management skills, which they might not otherwise receive at universities.

"The power to create new programs is in their hands. We believe that when students have opportunities to supplement their technical training with transferable or 'soft' skills, they will be more successful in their careers. Ultimately, connected,

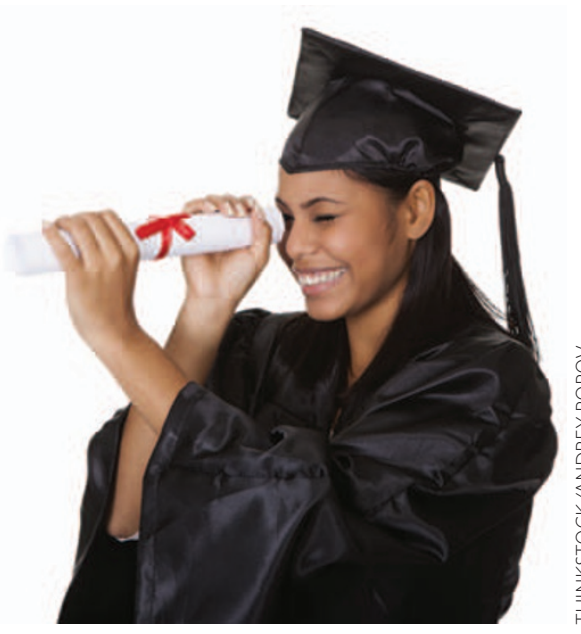

emphasized that strong support of students is a priority for OSA.

A relatively new initiative is the Young Minds Project of the European Physical Society (EPS). The main aim of this project is to encourage and support the professional skills of the next generation of physicists in Europe. The first Young Minds section was formed in 2010 at the Institute of Photonic Sciences (ICFO) in Spain. There are now 23 sections, with about 300 members from 13 countries (Spain, Italy, Ireland, Russia, Germany, UK, Ukraine, France, Switzerland, Turkey, Hungary, Denmark and the USA).

"Young Minds sections are different in that they are supported by the EPS, a physical society. However, SPIE and OSA have a longer history and more expertise in this kind of project, and we are often

skilled students become the strong optics community of the future," Fabian envisaged.

Jinxin Huang, who served as the President of the SPIE student chapter at the University of Rochester in 2012-2013, agrees. "My engagement of serving as a student officer in a SPIE chapter provided me with a platform for exchanging ideas with experts and student peers worldwide, as well as connections and access to resources in both academia and industry. These experiences have helped me to enhance my professional skills and develop a global vision of the field, which are of great value to my research and long-term career goals."

The first SPIE student chapter was formed in 1997 at the University of Central Florida, USA, and the program started to expand in 2004. The number of chapters has subsequently grown by roughly $20 \%$ per year. There are now 248 SPIE student chapters formed by $60 \%$ of SPIE student members.

OSA is also witnessing positive growth in its student chapters. In April 2013, it had more than 300 OSA student chapters in 56 countries, and $72 \%$ of student chapter members were located outside the USA. In a press release, Elizabeth Rogan, the CEO of OSA, stated, "the expansion of our student chapter program reflects the growing interest students have in creating an effective professional network and their strong desire to belong to the top professional society in the field." Rogan inspired by them. As the aims are the same, $40 \%$ of Young Minds Sections come from SPIE and OSA student chapters, and we work together," said Antigone Marino, the Chair of the Young Minds Project.

Fabian concurs, "In the end, the students are the driving force, and SPIE encourages them to build a governance structure that works best for them. The more resources students can access from professional societies, the better off they will be."

Student involvement is highly valued by senior members of the community, and travelling and visiting lecturer grants offered by SPIE and OSA support network building between them. The engagement of student chapters with the general public should not be understated either. According to Fabian, SPIE tracks how many members of the public student chapters reach each year through their educational activities - in 2013, it was a staggering 72,000 people, ranging from elementary school students to senior citizens. "Student chapters do an amazing job in raising the profile of optics and photonics at their campus and in the community," Fabian said with evident pride.

The role students play in promoting optics and photonics should not be underestimated. With the additional support and grants IYL 2015 will spawn, surely students will help promote the importance of light to another horizon. 